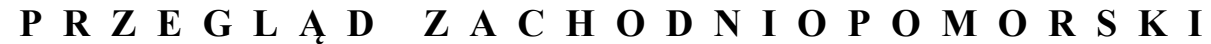 ROCZNIK XXXV (LXIV) ROK 2020 ZESZYT 3
}

\section{$\begin{array}{lllllllll}\mathbf{A} & \mathbf{R} & \mathbf{T} & \mathbf{Y} & \mathbf{K} & \mathbf{U} & \mathbf{L} & \mathbf{Y}\end{array}$}

\author{
ANDRZEJ TALARCZYK \\ https://orcid.org/0000-0003-0101-006x \\ Uniwersytet Szczeciński \\ e-mail: andrzej.talarczyk@usz.edu.pl
}

\section{Pomeranus non CANTAT? - UWe Johnson I Pomorze. TOPOS UTRACONEJ (PIERWSZEJ) OJCZYZNY LUB: $S K A D D$ POCHODZE, TEGO JUŻ NIE MA ${ }^{1}$}

Słowa kluczowe: Uwe Johnson, beletrystyka, literatura niemiecka, Niemcy (NRD), rok 1956, Pomorze, mała ojczyzna, konkretna utopia, bezdomność duchowa, powinowactwo duchowe

Keywords: Uwe Johnson, literary fiction, German literature, Germany (GDR), history of 1956, Pomerania, small homeland, concrete utopia, spiritual homelessness, spiritual affinity

„Wakacje letnie spędzałem regularnie

u dziadków, rodziców matki, na wsi na wyspie Wolin, która jest teraz polska"²

W prawie już nie do ogarnięcia literaturze sekundarnej o Uwem Johnsonie i jego twórczości dyskutuje się ciągle żarliwie na temat tego pisarza. Informuje o tym

1 Tekst jest poprawioną i uzupełnioną wersją publikacji Pomeranus non cantat - Uwe Johnson und Pommern oder wo ich her bin das gibt es nicht mehr, opublikowanej w tomie pokonferencyjnym Provinz als Zentrum. Regionalität in Literatur und Sprache. Ein polnisch-deutsch-nordisches Symposium, red. Dietmar Albrecht i in. (Akwizgran: Shaker, 2007) 105-120 (= Polygon. Jahrbuch des Instituts für moderne Fremdsprachen an der Naturwissenschaftlich-Technischen Universität Norwegens Trondheim 3 [2007]).

2 Wilhelm Johannes Schwarz, Der Erzähler Uwe Johnson (Bern-München: Francke, 1970), 90. Wszystkie tłumaczenia w tekście - Andrzej Talarczyk. 
bardzo obszerne zestawienie bibliograficzne, wydane w 1999 roku w renomowanej stuttgarckiej oficynie wydawniczej Metzlersche Verlagsanstalt ${ }^{3}$.

Spektrum spornych zagadnień i problemów, do których należy wiele szczegółów związanych również z biografią tego pisarza, w tym dokładnej daty jego śmierci lub czy miejscowość Jerichow w jego literaturze jest miastem w obecnym landzie Saksonia-Anhalt, czy ma również jakieś odniesienia biblijne, czy może jest syntezą wielu wątków różnego rodzaju, jest bardzo szerokie. Pojawiła się nawet teza, że badania nad twórczością Johnsona znajdują się w fazie początkowej ${ }^{4}$. Wynika to przede wszystkim z faktu, że rzeczywistość, jaką opisywał, leżała po drugiej stronie żelaznej kurtyny, a recepcji jego twórczości mogli dokonać czytelnicy, którzy jej nie znali i wiedzę o niej czerpali prawie wyłącznie z medialnego przekazu, który również nie był wolny od ideologicznej perspektywy narracyjnej. Z pewnością przełomowość roku 1989 przyniosła wiele nowych perspektyw postrzegania, które wniosły nowe wymiary recepcji jego twórczości. Do początku lat siedemdziesiątych minionego stulecia, a więc do momentu pojawienia się „,nowej wrażliwości” („neue Innerlichkeit”) w literaturze (zachodnio) niemieckiej, problematyka „małej ojczyzny” nie była dostrzegana jako jeden z centralnych motywów w prozie Johnsona. Stosowanie tego (w Niemczech historycznie zdyskredytowanego) terminu było w tamtym czasie unikane? ${ }^{7}$ Pociągało

${ }^{3}$ Por. Nicolai Riedel, Uwe Johnson-Bibliographie 1959-1998 (Stuttgart-Weimar: Metzler, 1999). Zestawień dotyczących okresu późniejszego dokonuje w formie internetowej Uwe Johnson-Forschungsstelle, placówka badawcza Uniwersytetu Rostockiego. W katalogu Niemieckiej Biblioteki Narodowej pod nazwiskiem pisarza figurują (wg stanu na 17.07.2020 r.) 334 pozycje. W Archiwum Uwego Johnsona (Uwe Johnson-Archiv) ma powstać w ciągu 24 lat edycja krytyczna wszystkich pism tego pisarza i to zarówno w wersji papierowej, jak i elektronicznej, co jest projektem pionierskim $\mathrm{w}$ germanistyce.

${ }^{4}$ We wstępie do pierwszej edycji nowego periodyku dotyczącego badań nad twórczością pisarza można przeczytać: „Nie umniejszając wartości dotychczasowego dorobku, znajdują się one w wielu aspektach dopiero na początku. Ważne problemy dotyczące jądra epiki zostały sformułowane. Natomiast dokładne analizy mniejszych tekstów, prac eseistycznych, krytyk telewizyjnych lub pracy Johnsona jako tłumacza i lektora podręczników szkolnych muszą jeszcze nastąpić. To samo dotyczy badań nad recepcją literacką" (Johnson-Jahrbuch 1 [1994]: 8).

5 Termin „Innerlichkeit” powstał w okresie oświecenia i dotyczy kategorii „,szczególnej wrażliwości, duchowości” ludzi tego okresu, co było powiązane z procesami emancypacji niemieckiego mieszczaństwa we wszystkich sferach życia społecznego.

${ }^{6}$ Pojęcie „Heimat” nie ma w zasadzie odpowiednika w języku polskim. Na początku lat 90. ubiegłego wieku pojawiła się u nas kategoria opisowa „mała ojczyzna”. Wcześniej używano takich pojęć, jak „ojczyzna lokalna” lub „prywatna” czy „strony ojczyste”. Były one tylko formami opisowymi tej kategorii pojęciowej.

7 Zdyskredytowanie to wynikało z jej nadużycia przez faszyzm, bo prowadziło, poprzez idealizację zasad etycznych, przez nacjonalizm rasy germańskiej, do volkizmu - niemieckiej 
to za sobą rozpatrywanie problemów szczegółowych w jego utworach w sposób nieadekwatny, częściowo całkiem zniekształcający ich istotę, co skutkuje również do dnia dzisiejszego licznymi nieporozumieniami i odmiennymi ocenami tych samych zagadnień ${ }^{8}$.

Także dystansowanie się osoby, której to dotyczyło, czyli samego pisarza, od wypowiedzi na własny temat, przyczyniło się do tego, że do dnia dzisiejszego istnieje w badaniach wiele nieporozumień i niedokładności w ocenie wielu nawet podstawowych faktów biograficznych. Debata dotycząca tez pierwszej całościowej biografii pisarza germanisty trondheimskiego Bernda Neumanna, która notabene jest do dnia dzisiejszego najobszerniejsza i najbardziej wnikliwa, ukazuje ten stan najdobitniej9.

Odnosi się to także do jednoznacznego przyporządkowania politycznego i geograficznego jego osoby. Urodzony na Pomorzu Johnson formułuje własne wypowiedzi dotyczące tego faktu wieloaspektowo, mimo pozornej jednoznaczności. W szczególności dotyczy to rzeczy najważniejszej dla tego przyporządkowania - przynależności w sensie małej ojczyzny dającej poczucie identyfikacji w aspekcie pochodzenia. Frankfurcki wydawca Siegfried Unseld, który przez ponad 20 lat był zaprzyjaźniony z Johnsonem, zrelatywizował powszechnie stosowany w badaniach wzorzec interpretacyjny przyporządkowania Johnsona do Pomorza, odbierając mu jednoznaczność. Postawił on w swoich komentarzach i wyjaśnieniach pod znakiem zapytania etykietowanie - poczynając od toposu „pisarz obydwu [części podzielonych - dop. A.T.] Niemiec”, do „piewca utraconej meklemburskiej małej ojczyzny"10. Autorzy tekstów w wydanym przez Rolanda

ideologii rasistowskiej. Por. na ten temat: Hubert Orłowski, Literatura w III Rzeszy, wyd 2 zm. (Poznań: Wydawnictwo Poznańskie, 1979.).

8 W wyniku tego wytworzyły się dwa przeciwstawne nurty badań johnsonowskich. Zwrócił na to uwagę Peter M. Schmitz w swojej wydanej w 2004 r. w wydawnictwie CLUEB Uniwersytetu Bolońskiego pracy Studien zum Heimatkonzept in Uwe Johnsons Roman „Jahrestage. Aus dem Leben von Gesine Cresspahl”. Wyróżnione są tam dwa wzorce interpretacyjne: 1. Mała ojczyzna jako inkarnacja niemieckiego konserwatyzmu (niemiecka duchowość); 2. Mała ojczyzna jako „przestrzeń historyczna i społeczna” (s. 42). Więcej na ten temat w rozdziałach II i III tego studium. Zasadniczy przełom przyniosły nie tylko w kontekście twórczości Johnsona, ale również dalszego rozwoju całej literatury zachodnioniemieckiej lat 80 . XX wieku. Por. Norbert Mecklenburg, Erzählte Provinz. Regionalismus und Moderne im Roman (Königstein im Taunus: Athenäum, 1982) i Hans-Georg Pott, red., Literatur und Provinz. Das Konzept 'Heimat' in der neuen deutschen Literatur (Paderborn-München-Wien-Zurych: Ferdinand Schöningh, 1986).

9 Bernd Neumann, Uwe Johnson (Hamburg: Ullstein, 2000).

${ }^{10}$ Siegfried Unseld, „Wohin ich in Wahrheit gehöre”, Du: die Zeitschrift für Kultur 619 (1992), 10: 48 . 
Berbiga i Erdmuta Winzislaua w 1993 roku tomie zbiorowym ,Wo ich her bin...”: Uwe Johnson in der $D D R^{11}$ zaznaczają także potrzebę przesunięcia do centrum przedmiotowych rozważań o pochodzeniu kategorii „małej ojczyzny”, która jednak ma być postrzegana w sposób bardziej zróżnicowany. Sygnalizuje to już tytuł tego zbioru, zawierający niedokończone zdanie z wypowiedzi bohaterki tytułowego opus magnum Johnsona, tetralogii Jahrestage, brzmiące w całości „Wo ich her bin das gibt es nicht mehr" ${ }^{12}$, co w tłumaczeniu na język polski znaczy „Skąd pochodzę, tego już nie ma”. Dla pełnej jasności: autor tego artykułu podziela pogląd, który w tekście Wilfrieda F. Schoellersa, zatytułowanym Eine Täuschung wie Heimat ${ }^{13}$, przyjmuje następującą postać słowną:

Meklemburgia jest niezaprzeczalnie krajobrazem literackim Uwego Johnsona: nie jako kulisy lub sentymentalnie wyidealizowana mała ojczyzna, lecz prowincja, w której pisarz rozeznaje się i z której rozszerzonej znajomości projektuje swój świat, który prezentuje czytelnikom ${ }^{14}$.

Jest ona krajobrazem literackim, który jednak, to trzeba koniecznie dodać, ma pokrewieństwo z pomorskim, lub ujmując ogólnie - północnoniemieckim, ponieważ kulturowe i topograficzne różnice między nimi są, jeżeli uwierzymy zapewnieniom Hansa Wernera Richtera, nieznaczne. W jego tomie wspomnieniowym Im Etablissement der Schmetterlinge w komentarzu na temat wyjazdu rodziny Johnsona z Pomorza znajdujemy następujące uwagi:

Kilka lat po urodzeniu Uwego [jego ojciec - dop. A.T.] przeprowadził się do Meklemburgii i [...] został Meklemburczykiem, jednakże różnica między Meklemburczykiem i Pomorzaninem jest bardzo mała. Mówią oni tym samym językiem, jeżeli nawet z małym dialektycznym przekoloryzowaniem, są często melancholijnie refleksyjni i posiadają figlarny humor. W dialekcie dolnoniemieckim nazywani są „,spoekenkieker”, a Pomorzanie - „kieken”, ale również często „spoeken” [jak Meklemburczycy]. On był „spoekenkieker” i posiadał ów melancholijny humor, który jest trudny do rozpoznania i może szybko irytować15.

${ }^{11}$ Roland Berbig, Erdmut Winzisla, red., ,, Wo ich her bin...”: Uwe Johnson in der DDR (Berlin: Kontext-Verlag, 1993).

${ }^{12}$ Uwe Johnson, Jahrestage, t. 1 (Frankfurt am Main: Suhrkamp, 1970), 386.

${ }^{13}$ Po polsku: „Złudzenie jak ojczyzna”.

${ }^{14}$ Wilfried F. Schoeller, „Eine Täuschung wie Heimat”, Du. Die Zeitschrift für Kultur 619 (1992), 10: 22.

${ }^{15}$ Hans Werner Richter, Im Etablissement der Schmetterlinge. 21 Portraits aus der Gruppe 47 (München-Wien: Hanser, 1986), 173. 
Perspektywa postrzegania Johnsona przez Hansa Wernera Richtera wychodziła poza aspekty regionalne (w węższym rozumieniu tego słowa) nawet wtedy, kiedy pisarz w momencie ukazania się jego powieści Mutmaßungen über Jakob ${ }^{16}$ osiedlił się w Berlinie Zachodnim, ponieważ Johnson jawił mu się na posiedzeniach Grupy 47 jako „bardzo nordycki, prawie egzotyczny [...] nordycki egzotyczny [...]. On mógł - jak kontynuował przywódca tej grupy literackiej - być człowiekiem z północy, wikingiem, można było sobie wyobrazić wszystko, co było wyobrażalne"'17.

Autor tetralogii powieściowej Jahrestage był więc dla niego człowiekiem pogranicza, który żył na granicy świadomości swojej „,egzystencji”, a więc jako „outsider"18. W kontynuacji tych analiz psychoanalitycznej i antropologicznej dochodzą dla naszych rozważań bardzo ważne stwierdzenia. Odnosząc się do warsztatu literackiego Johnsona, rozszerza Richter wypowiedź o rolę pochodzenia geograficznego, które uwzględnia również (z wielu innych powodów, o których później będzie szerzej mowa) pomorskość, w stwierdzeniu której decydujące są następujące przesłanki: „On wypracowywał swoje powieści i dopiero później je pisał. Krajobraz, z którego się wywodził, odgrywał przy tym decydującą rolę. Zbierał o nim wszystko, co było na jego temat osiągalne [...]”19.

Nie jest nieprawdziwe założenie, że wspólne pochodzenie było jedną z podwalin przyjaźni między nimi, która - w sposobie rozumowania Richtera - również włączała meklemburskość jako historycznie przekazaną kulturalną większą strukturę - i geograficznie, i topograficznie. Wyraził to tak:

Znowu była wspólnotowość pochodzenia, może chciał poprzez to powiedzieć, że tam przynależymy właściwie, do tego skrawka wybrzeża Bałtyku od Dziwny, od odnóg delty Odry, do Warnow, która pod Rostokiem wpływa do morza. Kochał ludzi tych okolic, rybaków, rolników, rzemieślników, znał ich język, dialekt dolnoniemiecki, i jak wydaje mi się, utrata tego krajobrazu, dopasowanego do niego otoczenia, czyniła go w jakiś sposób tułaczem. I wypędziła go pewnie później zupełnie, najpierw do Ameryki, później do Anglii, gdzie żył bardzo osamotniony na małej wyspie przy ujściu Tamizy. Jeżeli możemy mówić o braku zdolności

\footnotetext{
${ }^{16}$ Był to rok 1959, przed zbudowaniem muru berlińskiego, co nastąpiło 13 sierpnia $1961 \mathrm{r}$.

${ }^{17}$ Richter, Im Etablissement, 175.

18 Tamże, 176.

${ }^{19}$ Richter, Im Etablissement.
} 
asymilacyjnej, to jego to dotyczyło. Pozostał na zawsze Pomorzaninem, Meklemburczykiem, człowiekiem o melancholijnym sposobie życia, uparty i oryginalny ${ }^{20}$.

Z tego ludzkiego usposobienia wyprowadził Richter dalszy wniosek o „wewnętrznych” cechach Johnsona. Brzmiał on: „Może tak być, że język angielski był mu najbliższy, swojego rodzaju bardzo dalekie pokrewieństwo, które dotyczyło jego jako północnoniemieckiego mieszkańca wybrzeża"21.

U podstaw wszystkich tych bardzo, ,inspirujących” z punktu widzenia naszej analizy interpretacji leży zrozumienie fundamentalnego znaczenia pewnego rodzaju „utajonego pokrewieństwa duchowego, które sięga aż do krajobrazu”22, które łączy duchowo nawet pochodzącego z obszaru Łęgów Nadodrzańskich poetę Güntera Eicha. Było to więc uczucie wspólnotowości, które nie daje się ująć w żaden termin klasyfikujący, zwłaszcza jeżeli jest to pojęcie pochodzenia ideologicznego. Ta tak rozumiana i szeroko pojmowana przynależność do małej ojczyzny (co dokumentują przytoczone cytaty) nie ma nic wspólnego z polityką, w jej zawężonym rozumieniu jako polityka ,partyjna”, ponieważ - jak Johnson sam zdefiniował wzajemne relacje prywatności i polityki (światowej) - „system społeczny nie może w żadnym wypadku oferować małej ojczyzny. Strony ojczyste są w końcu obszarem prywatnym, to są osoby, to jest krajobraz, z którym można się utożsamiać"23.

Przytoczeniem tej sławnej i często cytowanej definicji zbliżamy się do treści, które łączą pomorskiego Meklemburczyka, lub jak chciał Hans Werner Richter, Pomorzanina i Meklemburczyka lub nordyckiego Niemca, z taką samoidentyfikacją poprzez przywiązanie do języka angielskiego. Są one odpowiedzią na dominację $\mathrm{w}$ tamtych czasach również w życiu społecznym polityki globalnej i artykułują nolens volens dążność do odseparowania się od nadużyć ideologicznych. Nie możemy nie zauważyć, że wówczas, przed podpisaniem w 1990 roku umowy granicznej między Polską i RFN, kwestia granicy była również z perspektywy rządu federalnego jeszcze otwarta i że nie tylko ziomkostwa ze Związku Wypędzonych, mimo wspaniałomyślnie w swojej stuttgarckiej „Karcie wypędzonych”

\footnotetext{
${ }^{20}$ Tamże, 178 i n.

${ }^{21}$ Tamże, 179.

${ }^{22}$ Richter, Im Etablissement.

${ }^{23}$ Schwarz, Der Erzähler, 87.
} 
z 5 sierpnia 1950 roku proklamowanej rezygnacji ze stosowania siły, nadal publicznie artykułowały roszczenia terytorialne ${ }^{24}$.

Przeniesienie się Uwego Johnsona 11 czerwca 1959 roku z NRD do Berlina Zachodniego nastąpiło - jak już zostało stwierdzone - w kontekście ukazania się powieści Domniemania w sprawie Jakuba. Było to jednocześnie początkiem jego zaistnienia w życiu literackim RFN. Zasygnalizowała to pisemna zapowiedź wydawnictwa Petera Suhrkampa w przededniu Frankfurckich Targów Książki, w której zaanonsowano, że Johnson „w zasadzie i może właśnie dopiero przybywa z Pomorza" ${ }^{25}$. Odpowiedź na taką kategoryzację zawarta w liście do Waltera Boehlicha, lektora tego wydawnictwa, brzmiała: „Ja nie jestem tak bardzo stamtąd. Ja tam żyłem tylko przez pewien czas. Jest zrozumiałe, że nieznaną osobę trzeba jakoś zasygnalizować, dlaczego nie tak. Stwierdzam to tylko dlatego, że było to dla mnie zabawne"26. W kontynuacji tego wywodu można przeczytać:

Niech Pan się nie martwi, że zrobił Pan ze mnie Pomorzanina. To można przeczytać nawet w metrykach uniwersyteckich: Pan taki i taki z Kamienia [Pomorskiego dop. A.T.] (Pomorze); ja byłem tam jednak krótki czas, w którym przychodzi się na świat, ponieważ w wiosce $w$ stronach rodzinnych mojej matki nie było szpitala. Zgadza się, ona jest z Pomorza, to jest co najwyżej środkowa część tego regionu. A mój dziadek był jeszcze obywatelem szwedzkim i żołnierzem. Muszę przyznać, że byłem nawet pół roku w Polsce. Natomiast po wojnie w Meklemburgii, mając dwadzieścia lat, przybyłem do Saksonii: ale to wszystko razem wziąwszy może tyle znaczyć, co Kammin na Pomorzu, który dzisiaj nazywa się całkiem inaczej i nie przynależy już do prowincji Pommern, jest to więc po prostu problem polityki światowej [...]. Chętnie spróbuję to Panu wyjaśnić, ale proszę, niech nie robi Pan $\mathrm{z}$ tego żadnych komunikatów. Za te wszystkie zawirowania losowe nie ponosimy odpowiedzialności, a w ogóle wydaje mi się, że ja pochodzę z Berlina: kiedy jestem gdzie indziej. Miał Pan pełne prawo [...] podawać mnie za Pomorzanina, ponieważ jest miasto, w którym istniał Urząd Stanu Cywilnego, i ponieważ mnie tam nie ma, jestem $\operatorname{stą}^{27}$.

${ }^{24}$ Ten problem społeczeństwa (zachodnio)niemieckiego widziany w szerszych konotacjach jako postawa obronna zarówno poszczególnych jednostek, jak i całych mas wobec problemu winy i współwiny, był przedmiotem analizy w znanym studium psychoanalitycznym „Von der Unfähigkeit zu trauern. Grundlagen kollektiven Verhaltens", które Aleksander i Margaretha Mitscherlich opublikowali w roku 1967 i które wywołało szerszą debatę społeczną.

${ }^{25}$ Cyt. za: Eberhard Fahlke, red., „Die Katze Erinnerung”. Uwe Johnson - eine Chronik in Briefen und Bildern (Frankfurt am Main: Suhrkamp, 1994), 14.

${ }^{26}$ List do Waltera Boehlicha z 1 sierpnia 1959 r. Cyt. za: Fahlke, ,Die Katze Erinnerung”, 14.

${ }^{27}$ List do Waltera Boehlicha z 5 sierpnia 1959 r. z Berlina-Dahlem z 5 sierpnia 1959 r. Cyt. za: Fahlke, ,Die Katze Erinnerung”, 15. 
Wypowiedź ta odnosi się do faktów podstawowych z życia pisarza: najpierw urodzin 24 czerwca 1934 roku w szpitalu miejskim w ówczesnym Kamieniu Pomorskim (Johnson posługuje się nazwą własną „Camin”, pisane nie przez „K”, żeby zdystansować się od ziomkostw), i do wioski Darzowice, skąd pochodzi jego matka. Pojawia się w niej również historyczne pojęcie „Pomorze” (Pommern), które właściwie należy kontekstualnie utożsamiać z pojęciem „Pomorze Tylne" (Hinterpommern). W kontynuacji tej wypowiedzi wspomniana jest również miejscowość Anklam na Pomorzu Zaodrzańskim (Vorpommern), położona w krainie, która z powodu odrębności dziejowej (m.in. okresowej przynależności do Szwecji) tylko warunkowo może być uważana jako część składowa (historycznego) Pomorza.

Johnson sugeruje dla usytuowania swojego pochodzenia pojęcie „Pomorze Środkowe" (Mittelpommern). Ta nazwa jednak w historiografii nie utrwaliła się i stąd posiada znaczenie tylko jako pojęcie geograficzne. Wiele lat później, w 1967 roku, kiedy uznanie i pozycja Uwego Johnsona w literaturze zachodnioniemieckiej były duże, zapytany przez jednego z wiodących krytyków literackich, Reinharda Baumgarta, o tę samą kwestię: „Panie Johnson. Pan urodził się na Pomorzu - wydaje mi się na Pomorzu Tylnym - zgadza się?” odpowiedział:

To nie zgadza się do końca, panie Baumgart. To miało miejsce nad Dziwną i należy właściwie do środkowej części. Poza tym był to raczej przypadek, ponieważ moja matka pochodziła z wioski na zachód od Dziwny. Pojechała do najbliższego dostępnego szpitala na drugiej stronie. Zatrzymałem się tam na krótki czas² ${ }^{28}$.

Rzucająca się w oczy pedantyczna dokładność tej wypowiedzi na temat prywatnej części jego biografii kontrastuje z dużą wstrzemięźliwością i lakonicznością jego późniejszych wypowiedzi na ten temat.

Świadomie praktykowane przez Johnsona dystansowanie się w wypowiedziach publicznych od sfery prywatnej jest również elementem jego poetyki. Znalazło to swoją formę artykulacyjną w tekście programowym „Berliner Stadtbahn" z roku 1961. Jest ono realizowane m.in. w formie zastosowania brechtowskiego „efektu obcości”. Dotyczy to również jego politycznych wypowiedzi, w których unika wszelkich koloryzowanych ideologicznie zobowiązań. Do estetycznych form artykulacji tej postawy należał również zakamuflowany, typowo

\footnotetext{
${ }^{28}$ Reinhard Baumgart, „Interview mit Uwe Johnson (am 2. August 1967 in München)”, w: Selbstanzeige. Schriftsteller im Gespräch, red. Werner Koch (Frankfurt am Main: Fischer-Taschenbuch-Verlag, 1971), 47.
} 
Johnsonowski humor, którego regionalne północnoniemieckie cechy są mocno zauważalne, lecz tylko dla współziomków i wtajemniczonych są całkowicie do rozszyfrowania. Stąd też pisarz chciał zejść z drogi wszelkiej dwuznaczności, co unaocznia uwaga wprowadzająca właściwe relacje problemowe, według której jego rodacy ,pracowali na rzecz wojny, nie znając jej pierwszej reguły: zdobyte jest zatrzymane" ${ }^{29}$. To (polityczne) przekonanie stało się też programem i skłoniło go do używania od samego początku poprawnych obecnych polskich nazw tych terenów z uzasadnieniem, które w odpowiedzi na pytanie ucznia ze szkoły w Leverkusen w Nadrenii Północnej-Westfalii przyjęło następującą formę:

Ówczesne niemieckie miejscowości, w których urodziłem się lub chodziłem do szkoły, podaję w polskiej wersji, ponieważ ona teraz jest obowiązująca. Po drugie Kościan lub Kamień Pomorski otrzymały swoje nazwy jako następstwo pierwszej i drugiej wojny światowej, i ja nie chcę znaleźć się w towarzystwie tych, którzy żądają rewizji tych wyników wojny; ponieważ taka rewizja może być dokonana za pomocą nowej wojny, zależy mi na tym, żeby uniknąć już werbalnego roszczenia odnośnie do utraconych ziem ${ }^{30}$.

Ujmując ten problem w kategoriach politycznych ówczesnych czasów, była to odważna postawa - świadome wyzwanie i prowokacja. Uwe Johnson baczył we wszystkich wypowiedziach na to, żeby odnośnie do miejsca urodzenia i chodzenia do szkoły podawać polską nazwę. Nie chciał być ideologicznie „,przyswojony", jak już zostało to zasugerowane wcześniej, przez ziomkostwo pomorskie. Zajmował przez całe życie postawę dystansu do różnych układów, powiązań politycznych, społecznych, a także do obydwu zwaśnionych obozów w okresie zimnej wojny.

Z drugiej strony Uwe Johnson nie był z pewnością ,wzorcowym” Pomorzaninem. Ta ocena była dla niego tak ważna, że umieszcza ją w swojej autoprezentacji w Niemieckiej Akademii Języka i Literatury w Darmstadt. Mowa ta została kilka dni później opublikowana w tygodniku „Die Zeit” pod tytułem wybranym przez redakcję, który brzmiał „Ich über mich selbst”, czyli „Ja o sobie”. W egzemplarzu autorskim, który można przeczytać w archiwum Uwe Johnson-Archiv, skorygował go na „Andere über mich”, czyli „Inni o mnie” i opatrzył tę korektę

\footnotetext{
${ }^{29}$ Uwe Johnson, Begleitumstände (Frankfurt am Main: Suhrkamp, 1980), 30.

${ }^{30}$ Uwe Johnson, „»»...Ich möchte nicht in die Nachbarschaft jener geraten, die eine Revision dieser Kriegsereignisse verlangen «. Fragen einer 10. Klasse der Hauptschule Küppersteg in Leverkusen vom 25.11.1970. Antworten vom 10.2.1971”, w: „Ich überlege mir die Geschichte...”. Uwe Johnson im Gespräch, red. Eberhard Fahlke (Frankfurt am Main: Suhrkamp, 1988), 133.
} 
znakiem zapytania. Szczegóły, również te dotyczące jego biografii, traktował bardzo poważnie; jeżeli nie wytrzymywały próby kolejnych weryfikacji według jego kryteriów, doprecyzowywał je. Nawet wtedy, kiedy jak tutaj, stawało się to przy wykluczeniu opinii publicznej. W mowie tej przedstawił wieloaspektowość stanu faktycznego swojego pochodzenia z zaskakującą otwartością. Czytamy tam:

Po pierwsze, Państwa nowy członek jest nazywany często, generalnie rzecz biorąc, „Pomorzaninem”, tak jakby była to wyczerpująca odpowiedź. Zgadza się w tym to, że jego matką była córką chłopa, jednak nie z tej tylnej części [Pomorza - dop. A.T.], o której w języku łacińskim można przeczytać, że „ona nie śpiewa”, lecz z tej części na zachód od Odry, w 1648 r. szwedzkiej i od 1720 r. pruskiej, co przynosi urodzonemu w 1934 r. zwierzchnictwo pruskiego premiera Hermanna Goeringa. Pierwsze dziesięć lat dorastałem na Pomorzu Zaodrzańskim kanclerza Rzeszy Adolfa Hitlera i nie do końca byłem postrzegany jako Pomorzanin z prawdziwego zdarzenia.

Z drugiej strony podoba się ludziom nazywać mnie Meklemburczykiem, jakby był to niezawodny wyróżnik. [...] W Meklemburgii przebywałem od jedenastego do dwudziestego piątego roku życia, a w dwudziestym szóstym zrozumiałem chyba, jak życzę sobie odpowiadać na żądania ludzi i urzędów, z którymi miałem do czynienia. Wiele przemawia za tym, że jestem Meklemburczykiem.

Jednak w Meklemburgii okresu powojennego traktowany byłem jako jeden z ,uciekinierów”. Nie było pomocne to, że Pomorze Zaodrzańskie w takim zakresie należało do reszty Niemiec, w jakim było podporządkowane radzieckiej administracji wojskowej. Ponieważ 1 marca 1947 r. zniknęła nazwa „Pomorze”, powstał sumaryczny skrót prawny „Land Meklemburgia”, a my byliśmy definitywnie z zewnątrz [...], a więc byliśmy „uciekinierami”, tyle tylko, że to określenie było bardzo surowo zabronione przez urzędy, w to miejsce wymagane było [określenie - dop. A.T.] „przesiedleniec”.

\section{$[\ldots]$}

Od 1949 r. byłem w oczach urzędów „obywatelem” Niemieckiej Republiki Demokratycznej, chociaż znów nikt nie pytał mnie o zgodę w tej sprawie. [...] Byłem również uważany lub traktowany jako „Berlińczyk Zachodni”, i to miasto podaję jako miejsce zamieszkania przez piętnaście lat. [...] Po dwóch i pół roku byłem prawie Nowojorczykiem. [...], ale wystarczyła przeprowadzka do Anglii i odnowa paszportu, żeby przemianować mnie na „obywatela Republiki Federalnej Niemiec”. 
Na koniec można by mówić o mnie, że jestem kimś, kto ma coś wspólnego z rzekami. Zgadza się, że wyrosłem nad Pianą w Anklam; przez Güstrow płynie Nebel, na rzece Warnow jeździłem do i z Rostoku, Lipsk oferował mi Pleisse i Elsterę. Manhattan opływają Hudson - i Eastern, i Northern, wspominam również rzekę Hackensack, a od trzech lat mam przed oknem Tamizę, która staje się Morzem Północnym. Ale to, do czego tak naprawdę przynależę, to gęsto zalesione pojezierze Meklemburgii od Plau do Templin, wzdłuż Eldy i Haweli $[\ldots]^{31}$.

Wywód ten potwierdza po raz kolejny, że jednoznaczne „przypisanie” Uwego Johnsona do jednego geograficznego obszaru właściwie nie jest możliwe. Pisarz był przez całe swoje życie (poszukującym) uciekinierem. To samo dotyczy jego politycznej tożsamości. Rozdwojenie, w którym żył, artykułowane jest w jednym z głównych tematów jego twórczości, który Stefanie Golisach w swoim wprowadzeniu do życia i twórczości pisarza zsyntetyzowała jako „sprzeczność między prywatną i publiczną egzystencją, jako pełne nieszczęścia [...] uwikłanie sfery prywatnej i publicznej, które jest w sposób widoczny symboliczne dla historii XX wieku"'32.

Z tego punktu widzenia Uwe Johnson był ciągle „obcym”33, jak nazwał go inny pisarz, Günter Kunert. Dotyczy go również to, co stwierdził na przykładzie wielu sławnych historyków niemiecki socjolog Siegfried Kracauer w swoim opublikowanym posthum w 1971 roku dziele historiozoficznym Geschichte - vor den letzten Dingen: oni byli emigrantami, i ten fakt determinował sposób ich postrzegania. Również oni sami widzieli postawione przed „sobą zadanie - obowiązek emigracji - przeniknięcia powierzchowności jej form objawiania się, żeby nauczyć się rozumieć ten świat od środka"34. Czegoś podobnego, chociaż przy innych społecznych przesłankach, doświadczył Johnson w swej wybranej samodzielnie emigracji. W Sheerness-on-Sea w pobliżu Londynu zmarł on najprawdopodobniej w nocy z 22 na 23 marca 1984 roku $^{35}$ w pełnej samotności, w nie do końca wyjaśnionych okolicznościach.

${ }^{31}$ Uwe Johnson, „Ich über mich selbst”, Die Zeit, 4.11.1977, 46.

${ }^{32}$ Stefanie Golisch, Uwe Johnson zur Einführung (Hamburg: Junius, 1994), 29.

${ }^{33}$ Por. Günter Kunert, „Ein Fremdling”, Du. Die Zeitschrift für Kultur 619 (1992), 10: 50-53.

${ }^{34}$ Siegfried Kracauer, Geschichte - vor den letzten Dingen (Frankfurt am Main: Suhrkamp, 1973), 103.

${ }^{35}$ Również data śmierci należy do tych stanów rzeczy, o które trwają spory w badaniach nad pisarzem. Por. Friedrich Denk, „Uwe Johnsons letzter Text”, Johnson-Jahrbuch 1 (1995): 259-262 i odpowiedź Bernda Neumanna w jego biografii Uwe Johnson, 16. 
Politycznie „sparzony”, pozbawiony na całe życie (w najszerszym znaczeniu tego słowa) stron ojczystych, budował swoim pisarstwem nową ojczyznę, eliminując poprzez to postawę wyłącznego opłakiwania jej utraty. Takie rozszerzające podejście do kategorii małej ojczyzny nie uzyskało w jego twórczości jednoznacznego geograficznego umiejscowienia. Był to „krajobraz duchowy” ${ }^{36}$, który jest szeroko zakrojoną częścią składową spójnej całości struktury jego dzieła literackiego. Większość jego bohaterów, których liczba wynosi około 200, jest jej pozbawiona. Wielu z nich pochodzi również z Pomorza. Pomorskość jest więc elementem współkształtującym przebieg fabuły, dającym jej wewnętrzną spójność. Jest ona w konsekwencji logiczną częścią składową Johnsonowskiego regionalizmu, który funkcjonuje jako prowincja (Meklemburgia lat trzydziestych) w produktywnej relacji biegunowego napięcia z Nowym Światem (inkarnacją którego jest Nowy Jork lat sześćdziesiątych) i ukazuje historię świata w stosunkach wzajemnych z małymi prywatnymi losami życiowymi.

Pojęcie małej ojczyzny, które nadaje wielości przedstawionych rzeczywistych i fikcyjnych wydarzeń więź wewnętrzną, jest wkomponowane i rozpatrywane w twórczości Johnsona wielowarstwowo i w wielu aspektach. Bernd Neumann wychodzi w interpretacji tego fenomenu w swoich politycznie nakierunkowanych analizach od tezy istnienia „społeczeństwa będącego w coraz mniejszym stopniu społeczeństwem »małej ojczyzny«, gdzie fetysz samochodu staje się perwersyjną zastępczą małą ojczyzną" ${ }^{37}$. Nawiązuje on tym wzorcem interpretacyjnym do skonstatowanej po 1945 roku „bezdomności człowieka” 38 i dodaje poprzez to problemowi małej ojczyzny także wymiar polityczny, w który włącza również stosunek Johnsona do NRD. Natomiast inny wybitny interpretator twórczości tego pisarza, Norbert Mecklenburg, tworzy całą typologię odniesień do małej ojczyzny, w której centrum znajduje się poszukiwanie „osobistej małej ojczyzny”39.

\footnotetext{
${ }^{36}$ Por. Eberhard Fahlke: „Heimat als geistige Landschaft: Uwe Johnson und Mecklenburg”, w: Über Uwe Johnson, red. Raimund Fellinger (Frankfurt am Main: Suhrkamp, 1992), 31 i Jan Badewien, Hansgeorg Schmidt-Bergmann, red., Mutmaßungen über Uwe Johnson: Heimat als geistige Landschaft [Beiträge der Tagung „Mutmaßungen über Uwe Johnson. Heimat als geistige Landschaft", 5.-7. März 2004 in Bad Herrenalb] (Karlsruhe: Evangelische Akademie Baden, 2005).

${ }^{37}$ Bernd Neumann, Utopie und Mimesis. Zum Verhältnis von Ästhetik. Gesellschaftsphilosophie und Politik in den Romanen Uwe Johnsons (Kronberg im Taunus: Athenäum, 1978) 283.

${ }^{38}$ Por. Han Egon Holthusen, Der unbehauste Mensch. Motive und Probleme der modernen Literatur (München: Piper, 1951).

${ }^{39}$ Por. Norbert Mecklenburg, „Ein Land, das ferner leuchtet”, w: Über Uwe Johnson, 335.
} 
Skala wzorców interpretacyjnych tego fenomenu jest dość szeroka i sięga od pojęcia „mała ojczyzna w okresie minionym”"40 do koncepcji „otwartej ojczyzny." ${ }^{\text {41 }}$ Dlatego nie podejmując się ich oceny, pozostaniemy przy niepodważalnym stwierdzeniu: regionalizm i - jako jego centralna część składowa - problematyka małej ojczyzny są fundamentalnymi częściami składowymi koncepcji narracji w całej twórczości Johnsona ${ }^{42}$. Sposób ich pojawiania się i przedstawiania jest zawsze adekwatny do tworzywa tematycznego i tematu. Problematyka małej ojczyzny wnosi zawsze ciężar gatunkowy nadający całości głębszy sens, tworząc nowe jądro wypowiedzi, jej istotę. Dlatego nie jest dziełem przypadku, że nośnikiem najgłębszych zwierzeń protagonistów jest dialekt dolnoniemiecki „plattdeutsch”. Z drugiej strony problematyka ta jest bardzo ściśle powiązana z życiem pisarza. Nie jest jednak postrzegana jako „nieodżałowana strata”, lecz została przemieniona w ,produktywną siłę poetycką"43. Chociaż miejscem akcji powieści Johnsona nie jest Pomorze, lecz Meklemburgia, i jest to najczęściej mieszanka fikcji literackiej i weryfikowalnej faktografii, nierzadko początek fabuły utworów jest usytuowany w tej dalekiej krainie przyjścia na świat pisarza. Wątki te pojawiają się rozproszone również we wszystkich możliwych związkach.

Pierwszym bohaterem wprowadzającym swoją osobą motyw pomorski do utworu literackiego jest Jakob Abs, protagonista pierwszej publikacji z 1959 roku, Mutmaßungen über Jakob ${ }^{44}$. Przybywa on z Pomorza do Meklemburgii jako uciekinier w kolumnie uchodźców i znajduje schronienie w domu Heinricha Cresspahla, ojca Gesiny, późniejszej centralnej postaci twórczości Johnsona. Za jego pośrednictwem przeżycia $\mathrm{z}$ dzieciństwa młodego Uwego znajdują bezpośrednią drogę do akcji powieści. Wspomnienia z czasów wczesnego dzieciństwa, naszkicowane jako pobyty wakacyjne na wyspie Wolin, są dla obydwu eudajmonią beztroski. Z perspektywy późniejszych doświadczeń „rzucenia na pastwę losu" historii światowej przez pobyt w szkole kształcącej elity faszystowskich

${ }^{40}$ Por. Jürgen Grambow, „Heimat im Vergangenen”, Sinn und Form. Beiträge zur Literatur 1 (1986): 134-157.

${ }^{41}$ Por. Schmitz, Studien.

${ }^{42}$ Por. Mecklenburg, Erzählte Provinz i tegoż, Die grünen Inseln. Zur Kritik des literarischen Heimatkomplexes (München: Iudicium, 1987).

${ }^{43}$ Por. Louis Ferdinand Helbig, Der ungeheure Verlust. Flucht und Vertreibung in der deutschsprachigen Belletristik der Nachkriegszeit (Wiesbaden: Harrassowitz, 1996).

${ }^{44}$ Uwe Johnson, Mutmaßungen über Jakob (Frankfurt am Main: Suhrkamp, 1959). Polskie wydanie w tłum. Sławy Lisieckiej ukazało się w 2008 r. w Warszawie w wydawnictwie Czytelnik pod tytułem Domniemania w sprawie Jakuba. 
Niemiec - Deutsche Heimschule w Kościanie w latach 1944-1945 - nabiorą w fabule utworu szczególnego znaczenia. Wpleciona w zaciszny (ustronny) krajobraz pomorski, jak została ta była niemiecka prowincja nazwana przez innego prominentnego jej mieszkańca, Christiana Grafa von Krokowa ${ }^{45}$, służy ta eudajmonia Johnsonowi, „niemieckie(mu) Faulknerowi’"46, jako jedna z zasad poetyki zorientowanej na postulat krytycznego przyswajania literackiego modernizmu B. Brechta. Bernd Neumann idzie w swojej ocenie tej kwestii nawet tak daleko, że konkluduje: „Refleks bardzo wczesnego szczęścia miał wkład do intensywności wspomnienia, które dzieło Johnsona łączy i różnorodnie z sobą splata" ${ }^{\text {"7 }}$.

Ta teza opiera się na następującym cytacie z Mutmaßungen, gdzie Jakub Abs, monologizując, stwierdza:

[...] a może to on sam był szczęśliwy w tej rozległej krainie nad wodą w dużym majątku, gdzie niepoliczone wozy drabiniaste stały obok siebie w słońcu, a ciężka woń kwitnących lip zalegała pod drzwiami chłodnych pokoi, nad przejrzystym lustrem wczesnej rzeki, w uległym trzasku trzciny pod ciężarem czółna?48

Idylla, jaką oferowało wolińskie życie wiejskie, kontrastowała z klimatem panującym w mieście powiatowym Kamieniu, miejscu urodzenia Johnsona. Hans Werner Richter, pisarz pochodzący z Banin, uzdrowiska morskiego położonego niedaleko na wyspie Uznam, opisuje panującą tam w latach trzydziestych atmosferę, a więc w czasie licznych pobytów małego Uwego u swoich dziadków, w następujący sposób:

Pewnego razu, długo przed narodzinami Uwego, demonstrowałem w tym mieście pod czerwonymi sztandarami, trzy lata przed przejęciem przez Hitlera władzy, lecz tam byli tylko Niemcy o światopoglądzie nacjonalistycznym, ludzie z SA i Stahlhelmu, tak więc zostaliśmy przegnani przez miasto wśród wyzwisk i wrzasków, wśród lecących ze wszystkich okien strasznych pocisków. Od tego czasu nienawidziłem i bałem się tego miasta. Ono było dla mnie uosobieniem reakcji i ograniczonego zacofania ${ }^{49}$.

\footnotetext{
${ }^{45}$ Christian Graf von Krockow, Die Reise nach Pommern. Bericht aus einem verschwiegenen Land (Stuttgart: Deutsche Verlags-Anstalt, 1985).

${ }^{46}$ Horst Bienek, Werkstattgespräche mit Schriftstellern (München: Hanser, 1962), 85.

${ }^{47}$ Neumann, Uwe Johnson, 22.

${ }^{48}$ Johnson, Domniemania, 88 i n.

${ }^{49}$ Richter, Im Etablissement, 173.
} 
Duch ten został najprawdopodobniej przeniesiony na polityczne nastawienie dziadków Johnsona i w dalszej kolejności na jego matkę, ponieważ, jak można przeczytać w biografii B. Neumanna, już we wczesnym dzieciństwie kulminowało zarysowujące się wyobcowanie w stosunku do rodziców w życzeniu znalezienia „dobrej matki”"50 i stworzeniu literackiej „życzeniowej [...] postaci ojca”, który po wstąpieniu do Volkssturmu nie wrócił z wojny. Dla takiej postawy dystansu jest oczywiście jeszcze wiele innych powodów. Swój początek mają one jednak w relacjach międzyludzkich i duchowych doświadczeniach w bezpośrednim otoczeniu pisarza. Jedną z nich są cierpienia Uwego Johnsona jako człowieka z powodu politycznego światopoglądu matki, który również po 1945 roku nie zmienił się. Dlatego też, w rostockim czasie studiów, znalazł w Angielce Alice Heksan „matkę zastępczą"52. Stąd również dochodzi u niego (widziane w szerszych związkach historycznych) uczucie, jak już stwierdziliśmy, skazania na łaskę i niełaskę polityki, ale również uczucie zdrady.

Początkiem tego stanu duchowego jest nadmieniony już pobyt w szkole w Kościanie pod Poznaniem w okresie od lata 1944 do stycznia 1945 roku. Te i dalsze historyczno-polityczne następstwa i skutki osobisto-rodzinnych relacji czynią z niego człowieka, który czuje się (w sensie politycznym) poganiany, ale nie wypędzony. Jest to udokumentowane w całej jego twórczości, wypowiedziach na temat literatury i komentarzach dotyczących polityki bieżącej. Układ ten skutkuje również określonym sposobem aksjologicznego podejścia do kategorii ojczyzny i rozumienia jej przez autora. Jest ono zbieżne z definicją filozofa Ernsta Blocha, którą kończy trzeci tom swojego traktatu Das Prinzip Hoffnung, według której małą ojczyzną jest to, co „pojawia się w dzieciństwie i gdzie jeszcze nikt nie był"53. Przytoczona definicja koresponduje z koncepcją filozoficzną

\footnotetext{
${ }^{50}$ Neumann, Uwe Johnson, 148.

${ }^{51}$ Tamże, 75.

${ }^{52}$ Tamże, 148.

${ }^{53}$ Ernst Bloch, Das Prinzip Hoffnung (Frankfurt am Main: Suhrkamp, 1985), 1628.
} 
jej autora, to znaczy z „teorią niejednoczesności” ${ }^{44}$ i „konkretnej utopii” ${ }^{55}$, co ma również, nolens volens, konotacje społeczno-polityczne.

Nie można pominąć tego, że jeżeli u Johnsona jest mowa o pomorskości, ma się na myśli także - i może przede wszystkim - wszechogarniający element wody, który tworzy ramy życia tego Meklemburczyka z wyboru. Można o tym przeczytać w monumentalnej biografii Neumanna:

Jego życie i pisanie zachodzi w pewnym sensie przez ciągle trwającą dominację rzek i mórz. Wyrósł w Meklemburgii, pochodzi [...] jednak z Pomorza. Określenie „Pomorzanie” znaczy jednak, według pierwotnego słowiańskiego znaczenia wyrazu, „ci, co mieszkają nad morzem”. To z drugiej strony robił Uwe Johnson przez całe swoje życie - również w swoich dniach berlińskich ${ }^{56}$.

Potwierdził to sam autor, pisząc do innego niemieckiego pisarza, Rolfa Italiaandera, 29 listopada 1979 roku list wysłany z ostatniego miejsca zamieszkania - angielskiego miasteczka Sheerness-on-Sea:

[...] stracić z pamięci miejsca obudzenia się to znaczyłoby zapomnieć o Dziwnie, która dla dziecka była szeroką wstęgą wody ze swoimi czarnymi łodziami, skrzynkami na ryby, obrosłych bujnym rozrostem trzęsawiskach i uginających się łąkach na ich brzegach. Ona pozostanie, jak Piana, która pod Karninem wypłukuje biały piasek, delikatny jak zegary słoneczne, jak Nebel, która gasi pragnienie przy moście dworcowym w Güstrow kosmyków liści wierzb płaczących. Niezastąpiony jest dzień, którym należy każdorazowo żyć na nowo i każdorazowo na nowo należy żyć dniem, który budzi się nad śluzą w Bützow, swoją przerwę obiadową robi pośród równin pod [miastem - dop. A.T.] Schwaan i wieczór obchodzi uroczyście na kołyszących się falach poprzecznych starego portu w Rostoku. Wszystkie rzeki są przechowywane w swoim czasie i wszystkie [...] po co są one wszystkie? Żeby

${ }^{54}$ „Teoria niejednoczesności” („Theorie der Ungleichzeitigkeit”) jest pojęciem, które zostało użyte przez Blocha po raz pierwszy w latach 30., żeby uczynić wytłumaczalnym atrakcyjność niemieckiego faszyzmu, i ponownie użyte w latach 60 . w odniesieniu do zagadnień imperializmu kulturowego i przeciw relatywistycznym teoriom o kręgach kultury. W swojej polemice $\mathrm{z}$ faszyzmem w wydanej w 1935 r. w Zurychu książce Erbschaft dieser Zeit Bloch odniósł niejednoczesność do istnienia obok siebie różnych poziomów postępu społecznego: nie wszystkie środowiska i obszary społeczeństwa przechodzą procesy postępu w taki sam sposób i tak szeroko. Powstaje na skutek tego pewne ,wykrzywienie” w stosunku do stopnia nowoczesności społeczeństwa.

${ }^{55}$ Ernst Bloch stworzył tę kategorię jako reakcję na marksistowską krytykę kategorii „utopia”. Bloch chce przeciwstawić się uogólniającemu charakterowi takiej krytyki i chce pokazać ważność i różnorodność utopii, w szczególności zaś nieodzowność antycypacji socjalnoutopijnych w kontekście praktyki marksistowskiej.

${ }^{56}$ Neumann, Uwe Johnson, 19. 
przypomnieć rzeki niegdysiejsze. Późniejsza bliskość z innymi rzekami była tylko po to, żeby przypominać wodę z przeszłości ${ }^{57}$.

Zaklinanie wspomnień pomorskiej rzeki staje się - podzielamy pogląd Neumanna - spojrzeniem wstecz na własne początki życia. Perspektywa tej retrospekcji jest bardziej wnikliwa, jeżeli sobie uświadomimy osobistą sytuację pisarza w momencie wyrażania tego poglądu. Był to rok 1979, a więc czas po rozwodzie i okres pogłębiającego się w związku z tym osamotnienia, którego nie były w stanie przełamać nawet frankfurckie „Wykłady z poetyki”, wygłaszane w tym czasie na tamtejszym uniwersytecie im. Johanna Wolfganga Goethego. Tak skłonny do wyczerpujących wypowiedzi jak przy tej okazji był on jednak rzadko. Tylko pierwsza biografia z roku 1970 Wilhelma Johannesa Schwarza wyraźnie ustosunkowuje się do początków życia. W umieszczonym w niej wywiadzie można przeczytać:

Czy Uwe Johnson ma jeszcze uczuciowe powiązania, stosunki jakiegokolwiek rodzaju z miejscem lub krajobrazem, gdzie się urodził?

Johnson: Nie. Przyznaję, że takie miejsce może być ojczyzną. Ja opuściłem to miejsce jednak za wcześnie, żeby dzisiaj jeszcze odczuwać głębsze uczucie dla niego. Między dziesiątym i szesnastym rokiem życia nie miałem politycznej ojczyzny, jedynie indywidualną osobistą małą ojczyznę. Berlin mógłby być moją małą ojczyzną, ponieważ tutaj mam osobiste powiązania różnego rodzaju ${ }^{58}$.

Również tutaj widoczne postawienie pod znakiem zapytania jednoznacznego przyporządkowania geograficznego pisarza jest zagadnieniem nie do końca uporządkowanym, lub może - nie do uporządkowania? Poprzez to jest ono jeszcze bardziej zagmatwane. W podsumowaniu kolejnej fazy życia, związanej wyłącznie z NRD, pisarz stwierdza:

W NRD jest tylko kilka osobistych miejsc: miejsca dzieciństwa, młodości. Tam są przyjaźnie, krajobrazy. Części człowieka. To jest przeszłość. Trwało to dziewięć lub dziesięć lat, może dwanaście. Obecnie to należy do przeszłości ${ }^{59}$.

${ }^{57}$ Uwe Johnson, List do Rolfa Italiaandera z 29 listopada 1979 r. z Sheerness-on-Sea, cyt. za: Fahlke, ,Die Katze Erinnerung”, 11.

${ }^{58}$ Schwarz, Der Erzähler, 88.

${ }^{59}$ Uwe Johnson, „Versuch, eine Mentalität zu erklären”, w: Ich bin Bürger der DDR und lebe in der Bundesrepublik. 12 Interviews, red. Barbara Gunert-Bronnen (München: Piper, 1970), 129. 
Jest to więc przeszłość nieodwołalnie zamknięta i miniona. Dalsze stacje życiowe „stygmatyzowanego" Uwego Johnsona, jako pozbawionego małej ojczyzny, czynią z jego życia przykład losu ludzkiego w „krótkim dwudziestym stuleciu" ${ }^{60}$. Jego ostatni zamiar osiedlenia się w Nowym Jorku, gdzie wszyscy pozbawieni małej ojczyzny czują się jak w domu, ukazuje wstrząsający obraz wewnętrznie rozdartego człowieka $\mathrm{w}$ również rozdartym świecie diametralnych przeciwieństw i w epoce zimnej wojny, która oznaczała pożegnanie z wszelkimi utopiami. To pożegnanie z iluzjami doprowadza w wypadku Johnsona do zajęcia proklamowanej w tetralogii powieściowej Jahrestage postawy „żyć przynajmniej ze znajomością stanu rzeczy”"61, jeżeli nie ma już moralnej Szwajcarii, do której możemy wyemigrować. Ten (nolens volens) polityczny (chociaż nie w sensie polityki bieżącej) zaczyn interpretacyjny, który w literaturze sekundarnej jest nadal za mało uwzględniany, wydaje się nam najbardziej odpowiedni, żeby przedstawić nie tylko światopoglądowe, ale również poetologiczne przesłanki kierujące Johnsonem, ponieważ w stuleciu ciągłych zdrad, jak XX wiek czasami jest opisywany, jest on swoim politycznym, filozoficznym $\mathrm{i}$ światopoglądowym zasadom wierny właściwie przez całe życie.

Czy ma to coś wspólnego z Pomorzem? W rzeczywistości dużo więcej, niż można by przypuszczać. Zakładając, że mała ojczyzna posiada funkcję życiodajną, możemy dzieła literackie tego pisarza postrzegać i traktować jako starania nadania sensu życiu, które legło w gruzach, przy pomocy siły wspomnieńn ${ }^{62}$ scalającej wszystko ponownie w jedność. W tej faktografii, ale i topografii, przedstawionej nadzwyczaj precyzyjnie w swoich powieściach, szuka on klucza do struktury historii i znajduje historię własnej osoby. Ta historia przeszkadza mu jednak w swojej modelowości w ponownym odnalezieniu tej małej ojczyzny. Co pozostaje jako wynik tych starań? Odpowiedź znajdziemy również w jego dziełach. Tą „schedą” jest „krajobraz, w którym dzieci dorastają i uczą się żyć”, jak można wyczytać w czwartym tomie jego opus magnum - Jahrestage. To osobiste odczucie małej ojczyzny przez główną bohaterkę tej powieści, Gesine Cresspahl,

\footnotetext{
${ }^{60}$ Por. Eric J. Hobsbawm, Wiek skrajności. Spojrzenie na Krótkie Dwudzieste Stulecie, tłum. Julia Kalinowska-Król, Marcin Król (Warszawa: Politeja, Świat Książki, 1999).

${ }^{61}$ Johnson, Jahrestage, t. 1, 210.

${ }^{62} \mathrm{Na}$ biurku pisarza stała figurka kota z drzewa hebanowego, nazwana „Katze Erinnerung”(„Kocia pamięć”). Kot jako symbol wolności w połączeniu z ulotnością pamięci symbolizował dla niego ustawiczną walkę o szczegóły uwiarygadniające prawdziwość opowiadanej historii.

${ }^{63}$ Uwe Johnson, Jahrestage, t. 4 (Frankfurt am Main: Suhrkamp, 1983), 1822.
} 
wyrażone w rozmowie z jej przyjaciółką z czasów szkolnych Anitą Gantlik, jest zgodne ze wszystkimi wypowiedziami autora w niezbyt licznych wywiadach dotyczących tej problematyki. Te wszystkie przeżycia i doświadczenia związane z mieszkaniem na Pomorzu, zarówno Zaodrzańskim, jak i Tylnym, obecnie Zachodnim, są czynnikami kształtującymi dalsze życie pisarza i niezbywalnym elementem składowym jego indywidualnej i bardzo złożonej koncepcji małej ojczyzny. Uwe Johnson jest „śpiewającym” Pomorzaninem, posługującym się prozą poetycką, żeby temu cyklowi życia i czasu nadać niepowtarzalny wyraz. Mała ojczyzna, również ta pomorska, pozostaje w sensie cytowanej definicji filozofa Ernsta Blocha wspomnieniem i zadaniem.

\section{Bibliografia}

\section{Źródła}

Baumgart, Reinhard. „Interview mit Uwe Johnson (am 2. August 1967in München)”. W: Selbstanzeige. Schriftsteller im Gespräch, red. Werner Koch, 47-56. Frankfurt am Main: Fischer-Taschenbuch-Verlag, 1971.

Johnson, Uwe. Begleitumstände. Frankfurt am Main: Suhrkamp, 1980.

Johnson, Uwe. Domniemania w sprawie Jakuba. Tłum. Sława Lisiecka. Posłowiem opatrzył Zdzisław Jaskuła. Warszawa: Czytelnik, 2008.

Johnson, Uwe. ,»...Ich möchte nicht in die Nachbarschaft jener geraten, die eine Revision dieser Kriegsereignisse verlangen«. Fragen einer 10. Klasse der Hauptschule Küppersteg in Leverkusen vom 25.11.1970. Antworten vom 10.2.1971”. W: „Ich überlege mir die Geschichte...”. Uwe Johnson im Gespräch, red. Eberhard Fahlke, 133. Frankfurt am Main: Suhrkamp, 1988.

Johnson, Uwe. „Ich über mich selbst”, Die Zeit, 4.11.1977.

Johnson, Uwe. Jahrestage. T. 1. Frankfurt am Main: Suhrkamp, 1970.

Uwe Johnson. Jahrestage. T. 4. Frankfurt am Main: Suhrkamp, 1983.

Johnson, Uwe. Mutmaßungen über Jakob. Frankfurt am Main: Suhrkamp, 1959.

Johnson, Uwe. ,Versuch, eine Mentalität zu erklären”. W: Ich bin Bürger der DDR und lebe in der Bundesrepublik. 12 Interviews, red. Barbara Gunert-Bronnen, 129. München: Piper, 1970.

\section{Opracowania}

Badewien, Jan, Hansgeorg Schmidt-Bergmann, red. Mutmaßungen über Uwe Johnson: Heimat als geistige Landschaft [Beiträge der Tagung „Mutmaßungen über Uwe Johnson. Heimat als geistige Landschaft", 5.-7. März 2004 in Bad Herrenalb]. Karlsruhe: Evangelische Akademie Baden, 2005. 
Berbig, Roland, Erdmut Winzisla, red. ,Wo ich her bin....”: Uwe Johnson in der DDR. Berlin: Kontext-Verlag, 1993.

Bienek, Horst. Werkstattgespräche mit Schriftstellern. München: Hanser, 1962.

Bloch, Ernst. Das Prinzip Hoffnung. Frankfurt am Main: Suhrkamp, 1985.

Denk, Friedrich. „Uwe Johnsons letzter Text”. Johnson-Jahrbuch 1 (1995): 259-262.

Fahlke, Eberhard. „Heimat als geistige Landschaft: Uwe Johnson und Mecklenburg”. W: Über Uwe Johnson, red. Raimund Fellinger, 311-333. Frankfurt am Main: Suhrkamp, 1992.

Fahlke Eberhard, red. „Die Katze Erinnerung”. Uwe Johnson - eine Chronik in Briefen und Bildern. Frankfurt am Main: Suhrkamp, 1994.

Golisch, Stefanie. Uwe Johnson zur Einführung. Hamburg: Junius, 1994.

Grambow, Jürgen. „Heimat im Vergangenen”. Sinn und Form. Beiträge zur Literatur. 1 (1986): 134-157.

Helbig, Louis Ferdinand. Der ungeheure Verlust. Flucht und Vertreibung in der deutschsprachigen Belletristik der Nachkriegszeit. Wiesbaden: Harrassowitz, 1996.

Hobsbawm, Eric J. Wiek skrajności. Spojrzenie na Krótkie Dwudzieste Stulecie. Tłum. Julia Kalinowska-Król, Marcin Król. Warszawa: Politeja, Świat Książki, 1999.

Holthusen, Han Egon. Der unbehauste Mensch. Motive und Probleme der modernen Literatur. München: Piper, 1951.

Kracauer, Siegfried. Geschichte - vor den letzten Dingen. Frankfurt am Main: Suhrkamp, 1973.

Krockow, Christian Graf von. Die Reise nach Pommern. Bericht aus einem verschwiegenen Land. Stuttgart: Deutsche Verlags-Anstalt, 1985.

Kunert, Günter. „Ein Fremdling”, Du. Die Zeitschrift für Kultur 619 (1992), 10: 50-53.

Mecklenburg, Norbert. Die grünen Inseln. Zur Kritik des literarischen Heimatkomplexes. München: Iudicium, 1987.

Mecklenburg, Norbert. „Ein Land, das ferner leuchtet”. W: Über Uwe Johnson, red. Raimund Fellinger. Frankfurt am Main: Suhrkamp, 1992.

Mecklenburg, Norbert. Erzählte Provinz. Regionalismus und Moderne im Roman. Königstein im Taunus: Athenäum, 1986.

Neumann, Bernd. Utopie und Mimesis. Zum Verhältnis von Ästhetik. Gesellschaftsphilosophie und Politik in den Romanen Uwe Johnsons. Kronberg im Taunus: Athenäum, 1978.

Neumann, Bernd. Uwe Johnson. Hamburg: Ullstein, 2000.

Orłowski, Hubert. Literatura w III Rzeszy. Wyd. 2 zm. Poznań: Wydawnictwo Poznańskie, 1979.

Richter, Hans Werner. Im Etablissement der Schmetterlinge. 21 Portraits aus der Gruppe 47. München-Wien: Hanser, 1986. 
Riedel, Nicolai. Uwe Johnson-Bibliographie 1959-1998. Stuttgart-Weimar: Metzler, 1999.

Schmitz, Peter M. Studien zum Heimatkonzept in Uwe Johnsons Roman „Jahrestage. Aus dem Leben von Gesine Cresspahl”. Bologna: CLUEB, 2004.

Schoeller, Wilfried F. „Eine Täuschung wie Heimat”. Du. Die Zeitschrift für Kultur 619 (1992), 10: 22.

Schwarz, Wilhelm Johannes. Der Erzähler Uwe Johnson. Bern-München: Francke, 1970.

Talarczyk, Andrzej. „Pomeranus non cantat - Uwe Johnson und Pommern oder wo ich her bin das gibt es nicht mehr". W: Provinz als Zentrum. Regionalität in Literatur und Sprache. Ein polnisch-deutsch nordisches Symposium, red. Dietmar Albrecht, Andreas Degen, Bernd Neumann, Andrzej Talarczyk. Akwizgran: Shaker, 2007 (= Polygon. Jahrbuch des Instituts für moderne Fremdsprachen an der Naturwissenschaftlich-Technischen Universität Norwegens Trondheim 3 [2007]).

Unseld, Siegfried. „Wohin ich in Wahrheit gehöre”. Du: die Zeitschrift für Kultur 619 (1992), 10: 48-49.

\begin{abstract}
AbstrakT
Uwe Johnson był przed 1989 rokiem postrzegany wyłącznie jako pisarz ,podziału Niemiec”. Urodzony na Pomorzu (Kamień Pomorski), okres dzieciństwa i wczesnej młodości spędził w Mecklemburgii. Po studiach germanistycznych w NRD przeniósł się w 1959 roku do Berlina Zachodniego. W tym samym roku ukazała się jego pierwsza powieść Mutmaßungen über Jakob (pol. Domniemiania o Jakubie, 2008), która - oprócz refleksji nad podziałem Niemiec w kontekście klimatu zimnej wojny dzielącej Europę na dwa obozy polityczne - szeroko opisuje wakacyjny czas spędzany do dziesiątego roku życia w Darzewicach koło Wolina. Jest to, patrząc przez pryzmat całej biografii autora, najszczęśliwszy okres w jego życiu i z tego powodu - punkt odniesienia do ukształtowania się światopoglądu w dwubiegunowym świecie indoktrynacji ideologicznej. Bohaterowie jego utworów pisanych prozą wywodzą się, podobnie jak Jakob Abs, główny bohater z wyżej wymienionej powieści, również z Pomorza. Tekst ten poświęcony jest analizie determinantów tożsamości regionalnej pisarza z perspektywy samorefleksji, w której kategoria małej ojczyzny w rozumieniu teorii konkretnej utopii (Ernst Bloch), zajmuje miejsce centralne - pokrewieństwa duchowego (Johann Wolfgang Goethe) oraz duchowej bezdomności (Siegfried Kracauer).
\end{abstract}




\title{
Pomeranus non cantat? Uwe Johnson and Pomerania: A TOPOS OF THE LOST (FIRST) HOMELAND OR WHERE I COME FROM DOESN'T ALREDY EXIST
}

\begin{abstract}
Uwe Johnson was perceived before 1989 exclusively as a writer of the division of Germany. Born in Pomerania (Kamień Pomorski), he spent his childhood and early youth in Mecklenburg. After obtaining his university degree in German philology in the German Democratic Republic, he moved to West Berlin. In the same year he published his first novel Mutmaßungen über Jakob (the Polish edition Domniemania w sprawie Jakuba appeared in 2008), which besides the reflection on the division of Germany in the context of the Cold War, dividing Europe into two political camps, extensively describes his holidays he spent until 10 years of age in Darzewice near Wolin. It was, looking through the prism of the author's whole biography, the most happy period in his life and therefore a point of reference for forming a worldview in a bipolar world of the ideological indoctrination. The characters of his novels written in prose, like Jakob Abs, the main character of the novel mentioned above, hail from Pomerania. The article provides an analysis of determinants of the author's regional identity from the perspective of self-reflection in which a central position occupies the category of small homeland as understood in the theory of concrete utopia (Ernst Bloch), as well that of spiritual affinity (Johann Wolfgang Goethe), and spiritual homelessness (Siegfried Kracauer).
\end{abstract}

